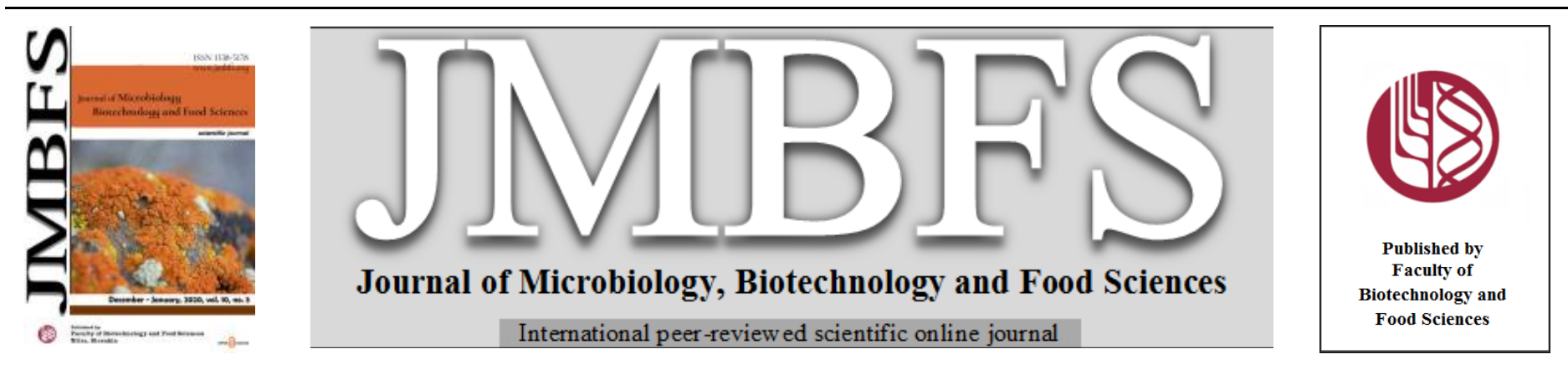

\title{
TREHALOSE LIPID AND RHAMNOLIPID SURFACTANTS AS PLANT GROWTH REGULATORS
}

\author{
Nataliia Koretska* ${ }^{l}$, Ilona Karpenko ${ }^{l}$, Olena Karpenko ${ }^{l}$, Halyna Midyana ${ }^{1}$, Volodymyr Baranov ${ }^{2}$ \\ Address(es): \\ ${ }^{1}$ Department of Physical Chemistry of Fossil Fuels of L.M. Litvinenko InPOCCC, National Academy of Sciences of Ukraine, Str. Naukova, 3a, Lviv, Ukraine, 79060. \\ ${ }^{2}$ Ivan Franko National University of Lviv, 4 Str. Hrushevsky, Lviv, 79005, Ukraine.
}

*Corresponding author: natalya.koretska@gmail.com

doi: $10.15414 / j m b f s .2020 .10 .3 .405-408$

\section{ARTICLE INFO}

Received 17.9. 2019

Revised 4. 3. 2020

Accepted 10. 8. 2020

Published 1. 12. 2020

Regular article

OPEN $\partial_{\text {ACCESS }}$

\begin{abstract}
The influence of biosurfactants of trehalose lipid nature (R. erythropolis Au-1) and rhamnolipid nature ( Pseudomonas sp. PS-17) on the efficiency of the absorption of $\mathrm{K}^{+}$and $\mathrm{Ca}^{2+}$ ions and plants growth was studied. The seeds of soybean, wheat and sunflower after the presowing treatment by the biosurfactants solutions were grown on a liquid nutrient medium. The residual contents of $\mathrm{K}^{+}$and $\mathrm{Ca}^{2+}$ ions in the medium were different for the variants with the biosurfactants and control (water). Based on these parameters, it was possible to value the stimulating effect of the biosurfactants on the plants' ability to absorb mineral elements from the nutrient medium. The plants after the pre-treatment by the biosurfactants absorbed on 10-40\% (trehalose lipids) and $27-61 \%$ (rhamnolipid biosurfactants) $\mathrm{K}^{+}$and $\mathrm{Ca}^{2+}$ ions more than control variants. The growth parameters of plants were increased on $17-24 \%$ (trehalose lipids) or $39-77 \%$ (rhamnolipid biosurfactants). The experiments with plants (wheat, soya and sunflower) were also conducted in field conditions. The results showed that the trehalose lipid and rhamnolipid biosurfactants provide an increase in crop yields on 19-23\% as well as the yield quality. The obtained data allowed to suggest a possible mechanism for the influence of surfactants on the plant growth.
\end{abstract}

Keywords: trehalose lipids, rhamnolipids, biosurfactants, plant growth stimulantion

\section{INTRODUCTION}

One of the priority tasks of modern biotechnology and agriculture is the creation of efficient and yet environmentally safe preparations for plants. Among them, microbial surfactants (biogenic surfactants, biosurfactants) can be promising agents for the improvement of plant growth due to their unique physico-chemical and biological properties and high efficiency. Biosurfactants have several advantages over the surfactants of synthetic origin, since they are biodegradable and low toxic, which determines their application in environmentally safe technologies (Pacwa-Plociniczak et al., 2011, Mulligan et al., 2014; Ramkrishna et al., 2010). The biosurfactants are able to influence the permeability of cell membranes of plants and microorganisms, the activity of various enzymes and other biologically active substances (Liang et al., 2010; Ostroumov, 2005), they can promote plant growth. In addition, they can improve the absorption of nutrients by roots or delignification of plant residues by microorganisms (Stacey et al., 2008). This combination of physico-chemical and biological properties of biosurfactants is very perspective for their use in modern industries (Mir et al., 2017; Banat et al., 2010; Abdel-Mawgoud et al., 2017). It is known that biosurfactants can be used in agriculture (Sachdev et al., 2013), in particular, they may act as plant growth regulators as well as means of plants protection (with antibacterial or antifungal activities) (Varnier et al., 2009; Vatsa et al., 2010; Sha et al., 2011).

Our previous studies have shown that trehalose lipids and rhamnolipids synthesized by the bacteria of genera Rhodococcus and Pseudomonas increase the permeability of cell membranes of microorganisms (Sotirova et al., 2008; Koretska et al., 2019). It is one of the reasons that biosurfactants enhance the action of biocides, phytohormones, etc. It also has been shown that biosurfactants can be used as effective growth stimulators for plants (Karpenko et al., 2013; Shcheglova et al., 2015). Based on the above, the aim of the work was to study the influence of trehalose lipids and rhamnolipids on the ability of plants to absorb mineral elements and to estimate the biosurfactant influence on the plant growth and yields of crop production.

\section{MATERIALS AND METHODS}

The bacterial strains $R$. erythropolis Au-1 (Rhodococcus erythropolis UCM Ac603) from the Ukrainian collection of microorganisms of D. Zabolotny Institute of Microbiology and Virology and Pseudomonas sp. PS-17 (Pseudomonas sp.
IMB B-7434) from Department of Physical Chemistry of Fossil Fuels of L.M. Litvinenko InPOCCC, National Academy of Sciences of Ukraine were used. Soybean Ivanka, winter wheat Zolotokolosa, sunflower Chumak were used in experiments with plants.

The results were statistically processed using Microsoft Excel 2013 software by the average error method.

\section{Production and isolation of biosurfactants}

Cultivation of biosurfactant-producing microorganisms was carried out on a rotary shaker (WL-2000, JV Electronic, Poland), $220 \mathrm{rpm}, 30^{\circ} \mathrm{C}, 5$ days in 750 $\mathrm{ml}$ Erlenmeyer flasks with $150 \mathrm{ml}$ medium.

\section{Trehalose lipids}

Cultivation of $R$. erythropolis Au-1 was carried out using the following nutrient medium $\left(\mathrm{g} / \mathrm{L}\right.$ : hexadecane $-20.0 ; \mathrm{NaNO}_{3}-3.0 ; \mathrm{K}_{2} \mathrm{HPO}_{4}-2.0 ; \mathrm{KH}_{2} \mathrm{PO}_{4}-2.0$; yeast extract -1.0 ; sodium citrate $-1.0 ; \mathrm{MgSO}_{4} \times 7 \mathrm{H}_{2} \mathrm{O}-0.5(\mathrm{pH} 7,0)$. Cells were collected by centrifugation at $6000 \mathrm{rpm}$ for $15 \mathrm{~min}$ and then washed with hexan to remove the residual hexadecane. Surfactants were extracted from cell mass with chloroform-isopropanol mixture $(2: 1, \mathrm{vol} / \mathrm{vol})$. The extract was evaporated under vacuum to constant weight. The main component of isolated surfactants were trehalose lipids (TLs) (Kretschmer et al., 1982). It was used in form of $0.01,0.05,0.10 \mathrm{~g} / \mathrm{L}$ solutions of TLs in the experiments.

\section{Rhamnolipid biosurfactants}

Cultivation of Pseudomonas sp. PS-17 was carried out using the following nutrient medium $(\mathrm{g} / \mathrm{L})$ : glycerol - 50.0; $\mathrm{NaNO}_{3}-4.0 ; \mathrm{K}_{2} \mathrm{HPO}_{4}-2.0 ; \mathrm{KH}_{2} \mathrm{PO}_{4}-$ $1.2 ; \mathrm{MgSO}_{4} \times 7 \mathrm{H}_{2} \mathrm{O}-0.5$; sodium citrate -5.0 ; yeast extract $-1.0(\mathrm{pH} 7,0)$.

Cells were separated by centrifugation at $6000 \mathrm{rpm}$ for $15 \mathrm{~min}$ and a cell-free culture liquid (CLS) was obtained. Rhamnolipid biocomplex (RBC) was precipitated from CLS by acidification to $\mathrm{pH} 3-4$ with $\mathrm{HCl}$ while keeping the mixture at $4^{\circ} \mathrm{C}$ for 3 hours (Mixich et al., 1997). RBC contained rhamnolipids and polysaccharide in ratio 4:1 (Patent of Ukraine, 2004). The following rhamnolipid containing products were used in the experiments: $0.01 \mathrm{~g} / \mathrm{L} \mathrm{RBC}$ solution and 1:200 diluted CLS of Pseudomonas sp. PS-17. 
Influence of biosurfactants on absorption of $\mathrm{K}^{+}$and $\mathrm{Ca}^{2+}$ ions and morphometric parameters of the seedlings

The residual content of $\mathrm{K}^{+}$and $\mathrm{Ca}^{2+}$ ions in the plant growth medium was estimated. For this purpose, the seeds of wheat and soybean were soaked for 3 hours in TLs solutions $(0.01,0.05,0.10 \mathrm{~g} / \mathrm{L})$, and sunflower seeds - in $0.01 \mathrm{~g} / \mathrm{L}$ RBC solution or 1:200 diluted CLS, control was soaked in distilled water. Then, the seeds were germinated on the moist filter paper according to the standard method (DSTU 4138-2002, 2003). After 7 days sprouts were placed in containers $\left(\mathrm{V}=0.5 \mathrm{~L}\right.$, by 10 sprouts) with Hellriegel liquid medium (g/L): $\mathrm{Ca}\left(\mathrm{NO}_{3}\right)_{2}$ $0.492 ; \mathrm{FeCl}_{3} \times 6 \mathrm{H}_{2} \mathrm{O}-0.025 ; \mathrm{KCl}-0.075 ; \mathrm{KH}_{2} \mathrm{PO}_{4}-0.136 ; \mathrm{MgSO}_{4} \times 7 \mathrm{H}_{2} \mathrm{O}-$ 0.123 (Grodzinsky \& Grodzinsky, 1973). The residual contents of $\mathrm{K}^{+}$and $\mathrm{Ca}^{2+}$ ions in the nutrient medium were measured on a flame photometer PFM-30MZ (USSR) after 48, 96, 240 hours of the experiment. The solutions of $\mathrm{CaCO}_{3}(0.5$ $\mathrm{g} / \mathrm{L})$ and $\mathrm{KCl}(0.5 \mathrm{~g} / \mathrm{L})$ were used as standards. The amount of mineral elements absorbed by the plants was estimated as the difference between the initial and residual ions content in growth medium.

After the determination of the ions absorption by plants the morphometric parameters of the seedlings were estimated: mass and length of roots and shoots. All variants of experiment were carried out in triplicates (Lakin, 1990).

\section{Effect of biosurfactants on plants in field experiments}

The influence of biosurfactants on plant growth in field conditions was studied. For this purpose, the soybean and winter wheat seeds were soaked for 3 hours in $0.05 \mathrm{~g} / \mathrm{L}$ TLs solution; sunflower - in $0.01 \mathrm{~g} / \mathrm{L}$ RBC solution or 1:200 diluted CLS, control - in distilled water. The treated seeds were sown in open ground on $10 \mathrm{~m}^{2}$ plots. Wheat grew for 10 months, soybean -4 months, sunflower -3 months (Trybel et al., 2001, Dospehov, 1985). The experiment was carried out in tetraplicates, the harvest was determined from each plot in grams per $\mathrm{m}^{2}$.

The qualitative characteristics of the harvest were determined: mass of 1000 seeds (DSTU ISO 520:2015, 2016), content of protein - using Kjeldahl method (GOST 13496.4-93, 2011), content of lipids - by according to GOST 10857-64 (2010).

\section{RESULTS}

Effect of biosurfactants on absorption of $\mathrm{K}^{+}$and $\mathrm{Ca}^{2+}$ ions and on growth of the seedlings

The effect of trehalose lipid and rhamnolipid biosurfactants on the efficiency of absorption of $\mathrm{K}^{+}$and $\mathrm{Ca}^{2+}$ ions by seedlings have been studied. The residual content of $\mathrm{K}^{+}$and $\mathrm{Ca}^{2+}$ ions in the plant growing medium was analyzed. It allowed to determine the amount of ions that were absorbed by seedlings. The results showed that plants after pre-sowing treatment by biosurfactants absorbed on $10-61 \% \mathrm{~K}^{+} \mathrm{i} \mathrm{Ca}^{2+}$ ions more than control (Fig.1).

In particular, RBC $(0.01 \mathrm{~g} / \mathrm{L})$ and CLS $(1: 200)$ had the same influence: for sunflower absorption of $\mathrm{K}^{+} \mathrm{i} \mathrm{Ca}{ }^{2+}$ ions increased by $27-61 \%$ if compared with control and depended on the ion nature and the exposure duration (Fig.1).

At the same time, TLs solutions promoted to somewhat lower absorption of $\mathrm{K}^{+}$ and $\mathrm{Ca}^{2+}$ ions than rhamnolipid surfactants: for soybean results were on $10-40 \%$ higher than control, for wheat - on 16-36\% (Fig.1)

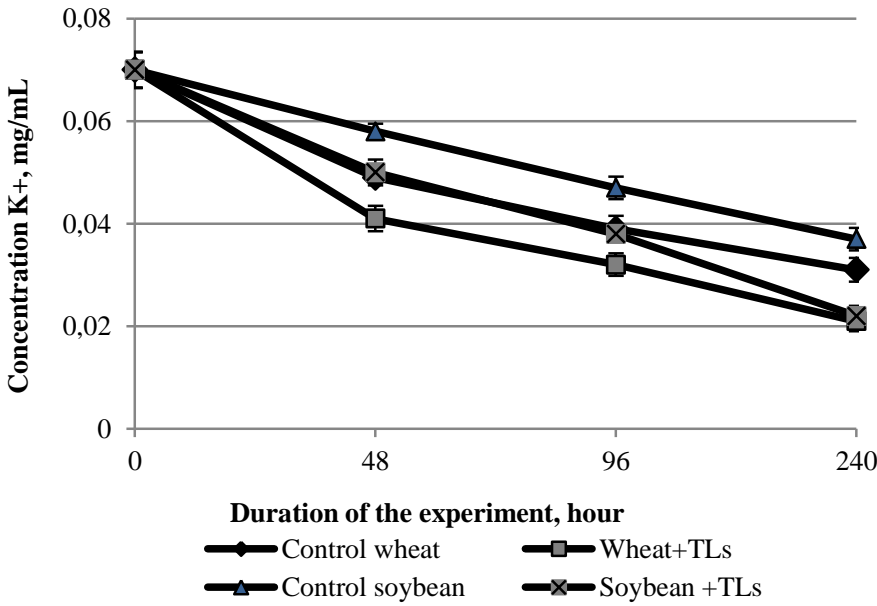

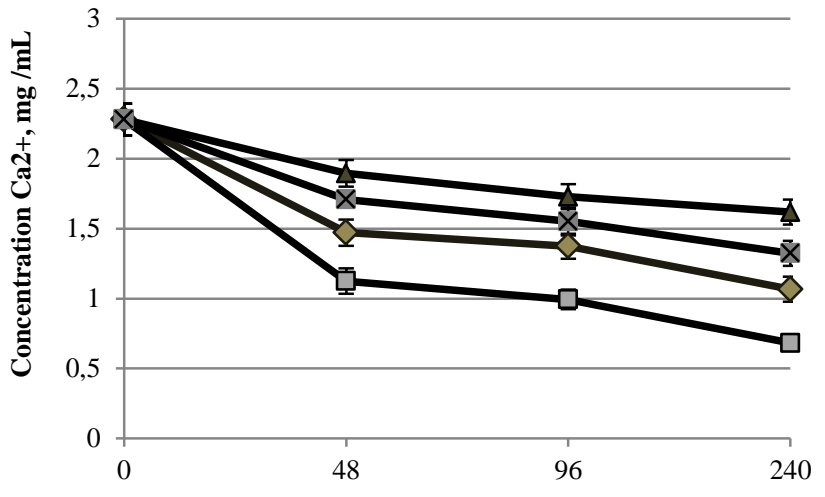

Duration of the experiment, hour
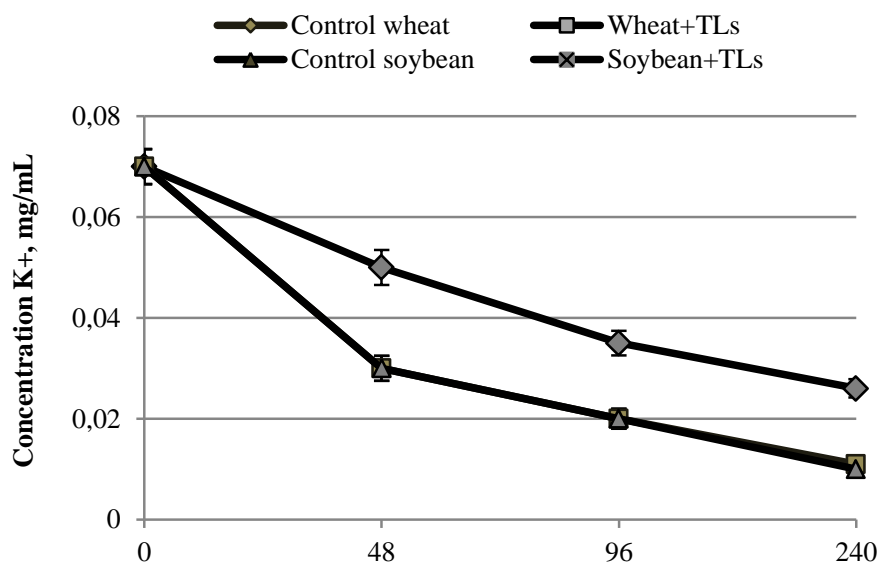

Duration of the experiment, hour

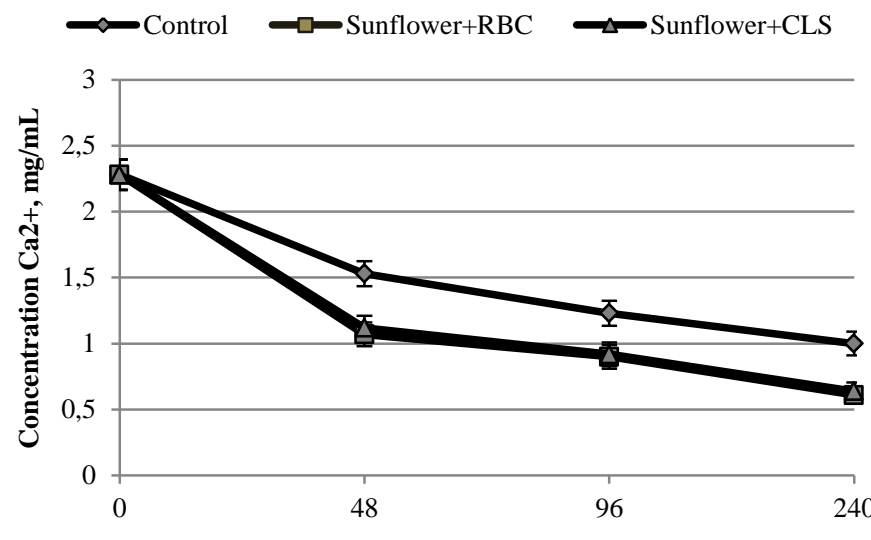

Duration of the experiment, hour

$\leadsto$ Control $\rightarrow$ Sunflower+RBC $\quad \longrightarrow$ Sunflower+CLS

Figure 1 The residual contents of ions in the plant growing medium. Seeds of plants were pre-treated with the surfactants: RBC - rhamnolipid biocomplex $(0.01 \mathrm{~g} / \mathrm{L})$, CLS - cell-free culture liquid of Pseudomonas sp. PS-17 (dilution 1:200), TLs - trehalose lipids $(0.05 \mathrm{~g} / \mathrm{L}$.

The influence of various TL concentrations on absorption $\mathrm{K}^{+}$and $\mathrm{Ca}^{2+}$ ions by plants was studied as well (Fig. 2). The results showed that the effect of all TL concentrations on the absorption of $\mathrm{Ca}^{2+}$ ions differed slightly: absorption increased for wheat seedlings on $11-18 \%$, and for soybean - on $32-36 \%$ compared with the control. The influence of $0.05-0.1 \mathrm{~g} / \mathrm{L}$ TLs on $\mathrm{K}^{+}$absorption by soybean was on $40 \%$ higher than control, and $0.01 \mathrm{~g} / \mathrm{L}$ TLs - only on $8 \%$. For wheat, the $0.05 \mathrm{~g} / \mathrm{L} \mathrm{TL}$ solution promoted the increase of the absorption of $\mathrm{K}^{+}$ ions on $32 \%$ compared with the control, whereas for $0.01 \mathrm{~g} / \mathrm{L}$ and $0.1 \mathrm{~g} / \mathrm{L}$ TL solutions - on only $7-10 \%$. Thus, the obtained data allowed us to assert that the influence of TLs on plants was highest at $0.05 \mathrm{~g} / \mathrm{L}$, therefore, this concentration was used in field experiments with plants. 


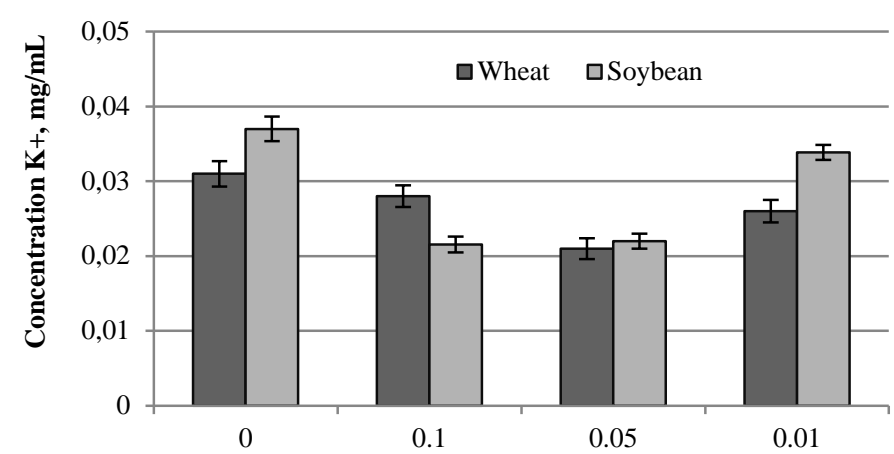

Concentration TL, g/L

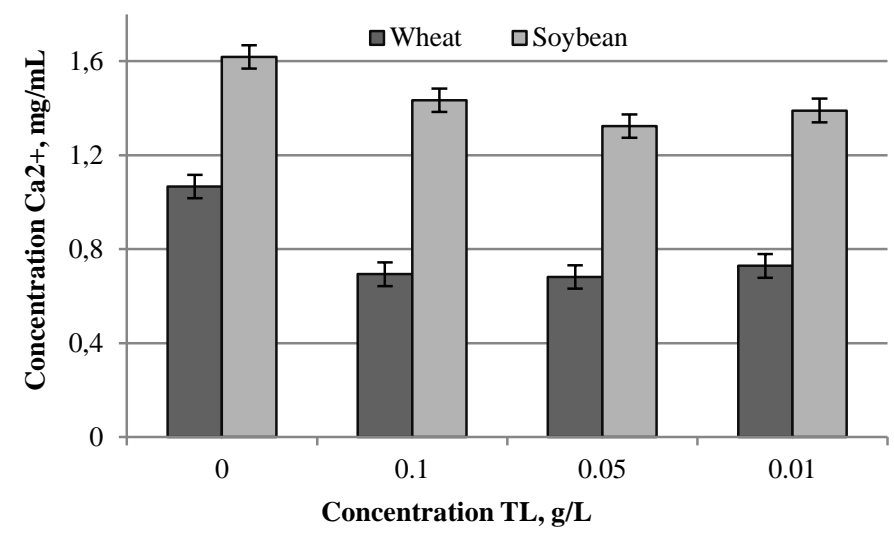

Figure 2 The residual content of ions in the plant growing medium after 240 hours. Seeds of plants were treated with TLs - trehalose lipids.

The influence of the biosurfactants on length and mass of roots and shoots of the seedlings of wheat, soybean and sunflower, which were used in previous experiment, was evaluated. The results showed that pre-sowing treatment of seeds by the biosurfactant solutions contributed to the improvement of plants morphometric indices (Fig. 3).
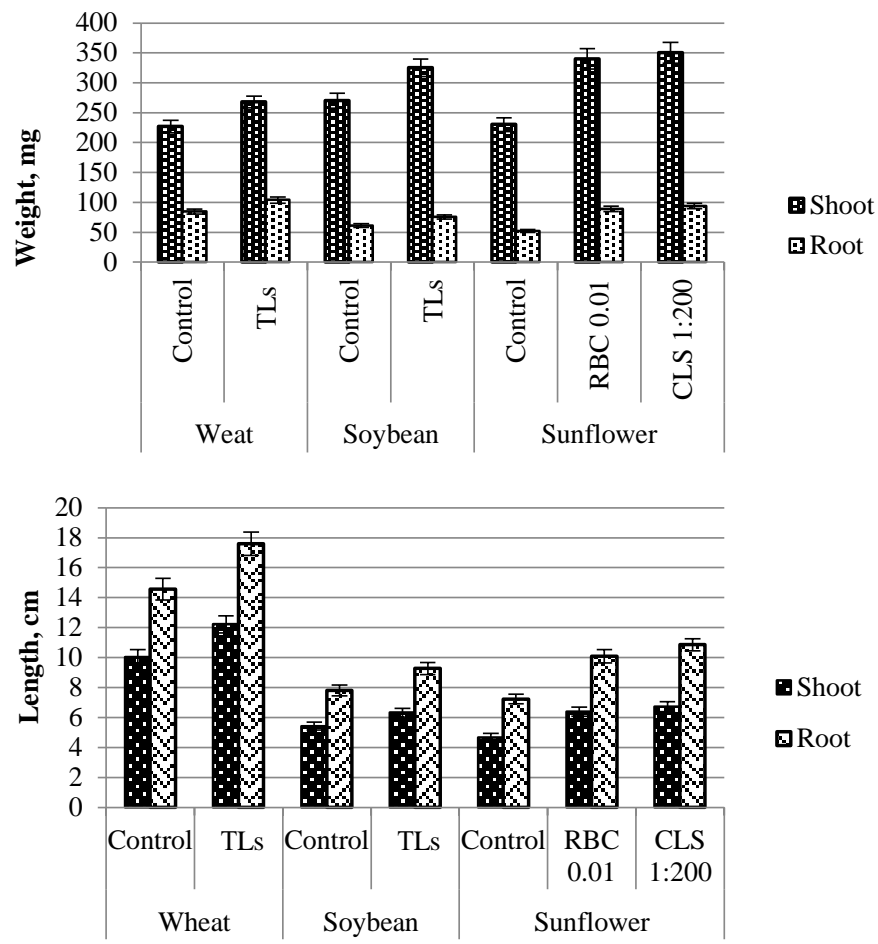

Figure 3 The influence of biosurfactants on morphometric indices of the seedlings. Seeds of plants were pre-treated with TLs - trehalose lipids $(0.05 \mathrm{~g} / \mathrm{L})$, RBC - rhamnolipid biocomplex ( $0.01 \mathrm{~g} / \mathrm{L}), \mathrm{CLS}$ - cell-free culture liquid of Pseudomonas sp. PS-17 (dilution 1:200).

Pre-sowing treatment of sunflower seeds by rhamnolipid surfactants contributed to increase growth parameters by $39-77 \%$, and for wheat and soybean by trehalose lipids - on $17-24 \%$ if compared with the control. At the same time, the effect of RBC (0.01 g/L) and CLS (1: 200) on plant growth didn't differ significantly. Based on the obtained data, it was assumed that biosurfactants should improve plant growth.

\section{Influence of biosurfactants on plants in field experiments}

The effect of biosurfactants on plant growth has been also determined in field conditions. It was shown that pre-sowing treatment of seeds with TLs $(0.05 \mathrm{~g} / \mathrm{L})$, RBC $(0.01 \mathrm{~g} / \mathrm{L})$ or CLS (dilution 1:200) of Pseudomonas sp. PS-17 positively effects both the plant growth and the yield (Table 1). In particular, the use of rhamnolipid surfactants contributed to the increase the weight of 1000 seeds on $32.7-35.2 \%$ and the sunflower yield- on $23 \%$ compared with the control. The results showed that the qualitative indicators of the sunflower yield were significantly improved: the content of fats in the seeds increased on $17.2-20.2 \%$ compared to the control, and the protein content - on 10.0-11.6\% (Table 1).

Table 1 The influence of the biosurfactants on yield and its quality

\begin{tabular}{|c|c|c|c|c|c|c|}
\hline \multirow[b]{2}{*}{$\mathrm{d}$} & \multirow{2}{*}{$\begin{array}{c}\text { Variants of seed } \\
\text { treatment }\end{array}$} & \multirow{2}{*}{$\begin{array}{l}\text { Weight of } 1000 \\
\text { seeds, } g\end{array}$} & \multirow{2}{*}{$\begin{array}{l}\text { Fat content in } \\
\text { seeds, } \%\end{array}$} & \multirow{2}{*}{$\begin{array}{l}\text { Protein content } \\
\text { in seeds, } \%\end{array}$} & \multicolumn{2}{|c|}{ Yield } \\
\hline & & & & & $\mathrm{g} / \mathrm{m}^{2}$ & $\%$ \\
\hline \multirow[b]{2}{*}{ Soybean } & Water (Control) & $139.9 \pm 5.1$ & - & - & $145.0 \pm 7.2$ & 100.0 \\
\hline & TLs $0.05 \mathrm{~g} / \mathrm{L}$ & $152.6 \pm 6.0$ & - & - & $172.3 \pm 8.6$ & 118.8 \\
\hline \multirow{2}{*}{ Wheat } & Water (Control) & $46.5 \pm 1.1$ & - & - & $285.2 \pm 12.3$ & 100.0 \\
\hline & TLs $0.05 \mathrm{~g} / \mathrm{L}$ & $48.5 \pm 1.2$ & - & - & $347.9 \pm 15.5$ & 121.9 \\
\hline \multirow{3}{*}{ Sunflower } & Water (Control) & $60.1 \pm 3.0$ & 36.5 & 12.9 & $390.0 \pm 15.3$ & 100.0 \\
\hline & RBC $0.01 \mathrm{~g} / \mathrm{L}$ & $81.3 \pm 3.4$ & 42.8 & 14.4 & $453.0 \pm 19.4$ & 116.2 \\
\hline & CLS 1:200 & $79.8 \pm 3.2$ & 43.9 & 14.2 & $481.0 \pm 20.1$ & 123.1 \\
\hline
\end{tabular}

Legend: TLs - trehalose lipids $(0.05 \mathrm{~g} / \mathrm{L}), \mathrm{RBC}$ - rhamnolipid biocomplex $(0.01 \mathrm{~g} / \mathrm{L})$, CLS - cell-free culture liquid of Pseudomonas sp. PS-17 (dilution 1:200).

The use of TLs practically didn't effect the mass of 1000 seeds, but the yield increased on $19 \%$ (for soybean) and on $22 \%$ (for wheat) compared to the control (Table 1).

\section{DISCUSSION}

The results shows that trehalose lipid and rhamnolipid surfactants have the ability to stimulate the growth of wheat, soybean and sunflower. The obtained data allow us to conclude that pre-sowing treatment of seeds with biosurfactants solutions promotes to increase plant growth parameters, yield, and its quality (as evidenced by the fat and protein contents in the collected sunflower seeds). These results are consistent with the literary data, in particular Sachdev \&Cameotra
(2013) reported that biosurfactants promote increasing of nutrient availability, uptake and efficient distribution in the soil, thus plant growth. Biosurfactants can protect plants against toxic substances of soil and phytopathogens. Singh et al. (2018) consider the potential role of biosurfactants in plant growth promotion as well as other biosurfactants applications related to improving the effectiveness of agricultural soils.

In our opinion, possible explanation of the stimulative action of biosurfactants on plants growth is their effects on the cell membranes. The experimental results showed that the pre-sowing treatment of seeds with biosurfactants solutions promotes the increase of the absorption of $\mathrm{K}^{+}$and $\mathrm{Ca}^{2+}$ ions by the seedlings. It can be explained by the ability of biosurfactants to increase bioavailability of exogenous compounds for plants via changing the permeability of cell 
membranes (Sotirova et al., 2009; Sotirova et al. 2012). According to the obtained results, it can be concluded that the stimulating effect of biosurfactants on plants can be associated with an increase in the permeability of cell membranes for nutrients. This assumption is supported by published data on the possibility of the formation of stable supramolecular complexes of membrane phospholipids with rhamnolipids (Pashynska et al., 2010). In our opinion, the formation of such complexes is associated with a change in the permeability of cell membranes, which occurs under the influence of biosurfactants in low concentrations. The result of this interaction is the long-term effect of biosurfactants on the growth of the root and shoot mass of plants. The surfactants can effect on cells due to formation of supramolecular complexes with membrane-bound enzymes (ATP-ase and phospholipase) (Sandstrom \& Cleland, 1989; Shumilina et al., 1998). The obtained results are also consistent with the reports that surfactants increase the bioavailability of various nutrients and water, contribute to the wetting of the soil and the distribution of nutrients in the soil as well as the absorption of nutrients by plants (Khadydja et al., 2016) Biosurfactants also have the ability to change the properties of the roots surface (D'aes et al., 2010)

Interesting results are that RBC and CLS have an equal effect on the uptake of $\mathrm{K}^{+}$ and $\mathrm{Ca}^{2+}$ ions by plants, but the yield of sunflower seeds (field experiment) was on $7 \%$ higher for CLS than the use of RBC. It is possible that other biologically active substances of the culture liquid of bacteria, in particular phytohormones, siderophores can effect on the plant growth (Tistechok et al., 2019).

The research allowed the determination of one of the possible mechanisms of the effect of the biosurfactants on plant growth (via the pre-sowing seed treatment). Thus, the experimental results and literature data indicate the prospects of the application of biosurfactants in the environmentally safe agricultura technologies.

\section{CONCLUSION}

The results of the work have shown that use of trehalose lipid and rhamnolipid biosurfactants for pre-sowing seed treatment allowed to inclease the yield on 16$23 \%$ if compared with the control. In our opinion, the improved absorption of mineral elements by plants may explain the stimulating effect of the biosurfactants on plants growth. Therefore, biosurfactants can be used for reducing of amount of mineral fertilizers that are introduced into soil. It's very important result for application of new effective and environmentally friendly preparations in agriculture. The obtained results indicate the prospects of application of biosurfactants as efficient and environmentally friendly substances for stimulation of plants growth in modern crop technologies. The development of this promising direction requires further practical research.

\section{REFERENSCES}

Abdel-Mawgoud, A. M., Stephanopoulos, G. (2017). Simple glycolipids of microbes: Chemistry, biological activity and metabolic engineering. Synthetic $\begin{array}{llll}\text { and } & \text { Systems } & \text { Biotechnology. } & 3(1),\end{array}$ https://doi.org/10,1016/j.synbio.2017.12.001

Banat, I. M., Franzetti, A., Gandolfi, I., Bestetti, G., Martinotti, M. G, Fracchia, L., Smyth, T. J., Marchant, R. (2010) Microbial biosurfactants production, applications and future potential. Appl Microbiol Biotechnol. 87, 427-444. https://doi.org/10,1007/s00253-010-2589-0

D'aes, J, De Maeyer, K, Pauwelyn, D. (2010) Biosurfactants in plantPseudomonas interactions and their importance to biocontrol. Environmental Microbiology Reports, 2, 359 - 372. https://doi.org/10,1111/j.17582229.2009.00104.x

Dospehov, VA. (1985). The field experiment method (with basics of statistical processing of research results). Moscow: Agropromizdat, 351 p. BBK 41,4.

DSTU 4138-2002. (2003).Seeds of agricultural plants. Methods for seeds testing. Kyiv: Derzhspozhivstandart Ukrayini.

DSTU ISO 520:2015 (ISO 520:2010, IDT). (2016). Cereals and legumes. Determination of the mass of 1000 grains (to replace GOST 10842-89 (ISO 520 77). Kyiv: Derzhspozhivstandart Ukrayini.

GOST 10857-64 (2010). Oil seeds. Methods of determining oil content. Kyiv: Derzhspozhivstandart Ukrayini.

GOST 13496.4-93 (2011). Fodder, mixed fodder and animal feed raw stuff. Methods of nitrogen and crude protein determination. Kyiv: Derzhspozhivstandart Ukrayini

Grodzinsky, AM, Grodzinsky, DM. (1973). A brief reference book on the physiology of plants. Kyiv: Naukova Dumka. p.591,

Khadydja, FD, Rufino, RD, Luna, MJ, Santos, VA, Sarubbo, LA. (2016) Biosurfactants: Multifunctional Biomolecules of the 21st Century. Int. J. Mol Sci.; 17(3): 401. https://doi.org/10.3390/ijms17030401

Karpenko OV, Koretska NI, Shcheglova NS, Karpenko IV, Baranov VI (2013) Gramineae plants growth stimulation by surface-active rhamnolipids. Biotechnologia acta. 6(6): 94-99. https://doi.org/10,15407/biotech6.06.094

Koretska N, Karpenko O, Baranov V, Lubenets V, Nogina T. (2019). Biological properties of surface-active metabolites of Rhodococcus erythropolis $\mathrm{Au}-1$ and their prospects for crop technology. Innovative biosystems \& bioengineering 3(2): 77-85. https://doi.org/10,20535/ibb.2019.3.2.165165

Kretschmer, A, Bock, H, Wagner, F (1982). Chemical and physical characterization of interfacial-active lipids from Rhodococcus erythropolis grown on n-alkanes. Applied and Environmental Microbiology, 4, 864-870,

Lakyn, H F. (1990). Biometrics. Moscow: Vyshcha shkola, 352 p. ISBN 5-06 000471-6.

Liang, YS., Yuan, XZ., Zeng, GM., Hu, CL., Zhong, H, Huang, DL., Tang, L, Zhao, JJ. (2010). Biodelignification of rice straw by Phanerochaete chrysosporium in the presence of dirhamnolipid. Biodegradation 21:615-624 https://doi.org/10,1007/s10532-010-9329-0

Mir, Sh., Jamal, P, Alama, Md. Z., Mir, A.,B., Ansari, A. H. (2017). Microbia Surface Tensio-active Compounds: Production and Industrial Application Perspectives. International Journal of Biotechnology and Bioengineering. 3(8), 273-292. https://doi.org/10.25141/2475-3432-2017-8.0273

Mixich J, Rothert R, Wullbrandt D. (1997). Process for the quantitative purification of glycolipids. United States patent 5656747A.

Mulligan, C. N., Sharma, S.K., Mudhoo, A. (2014). Biosurfactants: Research Trends \& Applications. Boca Raton: CRC Press, Taylor\&Francis Group. ISBN 9781466518230

Ostroumov, S. A. (2005). Biological effects of surfactants. New York: CRC Press, 279 p. ISBN 9780849325267

Pacwa-Płociniczak, M, Płaza, GA, Piotrowska-Seget, Z, Cameotra, SS. (2011) Environmental applications of biosurfactants: recent advances. Int. J. Mol. Sci. V. 12, 633-654. https://doi.org/10.3390/ijms12010633

Pashynska, V, Karpenko, O. (2010). Mass spectrometric study of rhamnolipid supramolecular complexes with membrane phospholipids. Supramolecular Systems in Chemistry and Biology: int. summer school, 6-10 September 2010: proc. of conf. Lviv, 135 p. http://dx.doi.org/10,7124/bc.0007FE

Patent of Ukraine, N 71792. 2004. Surface active biopreparation. Karpenko, OV, Martynyuk, NB, Vildanova, RI, Shulga, AN. Bull.N 12.

Sachdev, D. P., Cameotra, S. S. (2013). Biosurfactants in agriculture. Int J Appl Microbiol Biotechnol. 97, 1005-1016. http://dx.doi.org/10,1007/s00253-0124641-8.

Sandstrom, RP, Cleland, RE. (1989). Selective Delipidation of the Plasma Membrane by Surfactants Enrichment of Sterols and Activation of ATPase. Plant Physiology,90: 1524 - 1531 .

Sha, R., Jiang, L., Meng, Q., Zhang, G. \& Song, Z. (2011). Producing cell-free culture broth of rhamnolipids as a cost-effective fungicide against plant pathogens. J Basic Microbiol 51:1-9. https://doi.org/10,1002/jobm.201100295

Shcheglova, N S, Karpenko, OV, Vildanova, RI, Shulga, OM, Baranov, VI.(2015). Influence of microbial surfactants on the growth of legumes Biotechnologia Acta. 20158 (1):76-81, https://doi.org/10,15407/biotech8.01,076 Shumilina, EV, Zonova, NJ, Schipunov, JA. (1998). Influence of surfactants on the phospholipase DII activity. Biologycheskie membrane. 15 (4): 414 - 419.

Singh R, Glick B R, Rathore D. (2018). Biosurfactants as a biological tool to increase micronutrient availability in soil: A review. Pedosphere. 28(2): 170 189. https://doi.org/10.1016/S1002-0160(18)60018-9

Sotirova, AV., Spasova DI, Galabova DN, Karpenko E, Shulga A. (2008). Rhamnolipid-biosurfactant permeabilizing effects on gram-positive and gram$\begin{array}{llll}\text { negative bacterial strains. } \quad \text { Curr Microbiol. } & \text { 56(6):639-44. }\end{array}$ https://doi.org/10,1007/s00284-008-9139-3.

Sotirova, A, Spasova, D, Vasileva-Tonkova, E (2009). Effects of rhamnolipidbiosurfactant on cell surface of Pseudomonas aeruginosa. Microbiol Res. 164(3), 297-303. https://doi.org/10,1016/j.micres.2007.01,005.

Sotirova, A, Avramova, T, Stoitsova, S, Lazarkevich, I, Lubenets, V, Karpenko, E, Galabova, D (2012).The importance of rhamnolipid-biosurfactant induced changes in bacterial membrane lipids of Bacillus subtilis for the antimicrobial activity of thiosulfonates. Current Microbiology, 65 (5), 534-541, https://doi.org/10.1007/s00284-012-0191-7

Stacey, SP., McLaughlin, MJ., Çakmak, I, Hettiarachchi, GM., Scheckel, KG, Karkkainen, M. (2008). Root uptake of lipophilic zinc-rhamnolipid complexes. $J$ Agric Food Chem 56:2112-2117. https://doi.org/10,1021/jf07293

Tistechok, S, Mytsyk, Y, Fedorenko, V, Gromyko, O. (2019). Biosynthetic Potential of Actinomycetes from Helianthemum stevenii Rupr. Ex Juz. \& Pozd Rhizosphere. Innovative biosystems \& bioengineering. 3(2):105-113. https://doi.org/10.20535/ibb.2019.3.2.170129)

Trybel, SO, Siharova, DD, Sekun, MP, Ivashchenko OO, et all. (2001). Test methods and application of pesticides. Kyiv: Svit, 448 p.

Varnier, AL., Sanchez, L, Vatsa, P, Boudesocque, L, Garcia-Brugger, A, Rabenoelina, F, Sorokin, A, Renault, JH, Kauffmann, S, Pugin, A, Clement, C, Baillieul, F, Dorey, S (2009). Bacterial rhamnolipids are novel MAMPs conferring resistance to Botrytis cinerea in grapevine. Plant Cell Environ 32:178193. https://doi.org/10,1111/j.1365-3040,2008.01911,x.

Vatsa, P, Sanchez, L, Clement, C, Baillieul, F, Dorey, S. (2010). Rhamnolipid biosurfactants as new players in animal and plant defense against microbes. Int $J$ Mol Sci 11:5095-5108. https://doi.org/10,3390/ijms11125095 